DOI https://doi.org/10.36059/978-966-397-226-8-6

\title{
APPLYING CLIL METHOD WHILE REMOTE TEACHING
}

\section{Kuzmenko A. O., Kashyrina I. O.}

\section{INTRODUCTION}

In today's world, at the time of constant political, economic, technical, cultural and educational development and progress, views on the teaching of subjects / disciplines with the use of a foreign language are changing. First of all, the methods of internationalization are now being successfully implemented within the framework of international activities conducted by modern higher education institutions. Particular attention is paid to the development of new forms of education that must meet today's international requirements and standards in the context of transnational education. In current society at the age of information technology extreme development online studying of disciplines is getting more and more popular. It is not a new phenomenon; it is a routine. Communication technologies have developed rapidly and increased the demand for remote teaching.

Therefore, experienced academic staff members must find and use the most interesting and innovative methods of teaching their subject and be able to work and develop their activities in a cross-national direction via online resources making studying interesting and understandable. The main purpose of this work is to identify the main aspects of the methodology CLIL (Content and Language Integrated Learningsubject-language integrated learning) as an innovative method of training European professionals and clarify the Western experience of its implementation in the educational process in frames of remote teaching. This method is revealed as the main concept for preparing European specialists. The techniques of this method are worth to be discussed.

It should be noted that a foreign language is a key component for anyone intending to get an education and become a professional in a particular field, as well as to be able to increase their competitiveness and have an advantage among other professionals in the labour market. Therefore, future specialists try, in addition to a thorough study and 
knowledge of a particular field, be it law or psychology, etc., to study a foreign language deeply and thoroughly. Modern higher education cannot stay away from international methods of teaching subjects, undergraduates must look for opportunities for international development and be able to realize themselves internationally in terms of mobility strategy.

Various scholars have studied the issue of domestic education on the international stage, as well as various approaches to mastering subjects involving a foreign language on the model of European countries. Thus, A. Debych studied the process of integration of higher education at the international level ${ }^{135}$. In turn, R. Kulen studied aspects of training future professionals for professional activities at the international level ${ }^{136}$. In many educational institutions, the study of a foreign language finishes after the second year and the knowledge of a foreign language, mostly English, remains quite low. Thus, there is a need for convergence of foreign languages and professional disciplines during higher education for undergraduates.

A specialist in any field must be a comprehensively developed personality, not have a narrow understanding of one area, but be able to apply their subject through the prism of in-depth study, knowledge of the discipline and the formation of practical skills using a foreign language. Every specialist must be able to communicate in the field of their professional activity not only in their native language, but also in a foreign language.

Thus, having bi- / multi-lingual communicative competence means realization yourself as an international specialist ${ }^{137}$. Many scientists and scholars from around the world have studied the modernization of education. One of the subjects for research was the issue of improving the teaching of disciplines in the specialty in a non-native language and undergraduates' mastery of subjects taught in a foreign language.

\footnotetext{
${ }^{135}$ Брыксина И. Е. (2009). Концепция билингвального/бикультурного языкового образования в высшей школе (неязыковые специальности). Тамбов. 14 с.

${ }^{136}$ Дебич М. А. (2017). Інтернаціоналізація вищої освіти: світовий досвід : монографія. Суми. $291 \mathrm{c.}$

${ }^{137}$ Coelen R. (2016). A Learner-Centred Internationalisation of Higher Education. In Global and Local Internationalization. Boston. P. 35-42.
} 
Many scientists and scholars from around the world have studied the modernization of education. One of the subjects for research was the issue of improving the teaching of disciplines in the specialty in a nonnative language and undergraduates' mastery of subjects taught in a foreign language. In particular, M. Candelier proposed to organize the educational process in several languages by types, which included preparation for language learning from childhood, i.e. at the preschool level, which would allow the child to form an understanding of differences between languages and involve him in other languages and cultures; drawing a parallel between native and foreign languages, which would allow to compare and find a connection between native and foreign languages, and integrating language teaching and learning ${ }^{138}$.

Other scientists have considered multilingual education and immersion of a child in the bilingual sphere from childhood by his parents, which would allow the development of communicative and cognitive competence ${ }^{139}$. This technique helps to develop their thinking from the very beginning of the formation of personality, and also contributes to the formation of motivation to learn not only subjects but also foreign languages.

The issue of multilingual or bilingual education with in-depth study of a foreign language not only at the household level, but also at the professional level has become relevant around the world and requires its possible application in the domestic educational process.

\section{The concept of Content and Language Integrated Learning}

An effective way to achieve multilingualism at the household and professionally-oriented levels is one of the most popular approaches to learning subjects using a foreign language, namely the CLIL method, which involves learning non-language subjects in a foreign language.

\footnotetext{
${ }^{138}$ Candelier, M., Oomen, I. (2002). Linguarum. The Gateway to Languages. The Introduction of language awareness into the curriculum: Awakening to language. Council of Europe Publishing. P. 18.

${ }^{139}$ Филология и лингвистика в современном мире (2017). Международная научная конференция. Москва. 94 с.
} 
CLIL is better known in the Ukrainian environment as subjectlanguage integrated learning or context-language integrated learning is termed as:

- a means of mastering other disciplines, which in turn provide education for the undergraduate - a future specialist in the need for education, which gives the opportunity to rethink and improve their skills in communication in a native language;

- didactic methodology, which allows future specialists to form foreign language linguistic and communicative competences in the educational context, during which general skills and knowledge are formed.

David Marsh was the first to introduce the term CLIL and successfully introduced this method of studying a discipline in a foreign language more than twenty years later. Thus, any undergraduate has the opportunity to master the content of the subject in addition to the simultaneous study, improvement or practice of a foreign language ${ }^{140}$. In this context, language is not a goal for study, but is used as a means to master another subject, such as history, sociology, computer science, and so on. The main emphasis is on the fact that language is not the main object for learning, it acts as a tool that helps to learn other subjects. Undergraduates find some prospects to form, improve their communication skills ${ }^{141}$. Thus, undergraduates can immerse in the knowledge of a subject, and at the same time learn a foreign language.

CLIL develops the ability to self-education, mastery of innovative technologies, understanding the prospects and opportunities for their application, the ability to make decisions independently, adapt to new social and professional conditions, teamwork skills, the ability to overcome stress.

Content and Language Integrated Learning (CLIL) is a current trend in the internationalization of higher education in many countries. The CLIL method implies the simultaneous formation of subject and language competence of the student. This trend is becoming more

\footnotetext{
${ }^{140}$ Mehisto, P., Frigols, M.-J., \& Marsh, D. (2008). Uncovering CLIL. MacMillan. 240 p.

${ }^{141}$ Brewster, J. (2004). Content-based language teaching: a way to keep students motivated and challenged? Canterbury. P. 5.
} 
productive and is spreading among such developed countries as Belgium, France, Germany and others. Subject-language integrated learning occupies an honorable place in the international educational space, because it is a very effective way to prepare future professionals.

\section{Three models of CLIL}

It is important to study the models of subject-language integrated learning. The CLIL method has three models:

- $\quad$ soft (language-led);

- hard (subject-led);

- partial immersion.

The first soft model is aimed at the linguistic features of a special context. For instance, according to this model, undergraduates are taught selected topics in a foreign language. Undergraduates can learn a foreign language in part by learning new vocabulary in a specific context.

The next hard model is aimed at studying the subject in a foreign language for $50 \%$ of the curriculum. This CLIL model allows for a more in-depth study of the subject itself using already learned vocabulary, as well as to learn a new lexical component within the subject.

The third model of partial immersion, namely partial immersion, implies partial learning of a foreign language, in other words intermediate learning, i.e. a certain amount of hours is allocated for a particular subject to study some modules of this subject in a foreign language ${ }^{142}$.

According to the hard model, a vocabulary on this topic is already known, and the new terminology will be studied by undergraduates from a different angle, because according to this model, $50 \%$ of the time undergraduates will be taught in a foreign language. For example, learners in a foreign language will study how insects go through a life cycle or reproduce, using already known terminology and knowledge of the subject, in addition, this model introduces words on a broader topic, which allows undergraduates to learn more deeply and extensively.

\footnotetext{
142 Лалетина Т. А. (2012). Интегрированный подход и использование предметно-языковой интеграции при обучении иностранному языку. Красноярск. С. 16.
} 
According to the third intermediate type of CLIL, namely partial immersion, to study this subject in a foreign language, an academic staff member will take some selective topics, such as insect evolution, body structure, parasitic individuals that harm plants and others. It is believed that the hard model is the most effective and efficient, because half of the study time undergraduates are immersed in the language environment and have the opportunity to study the subject in a foreign language, develop their cognitive and communication skills, including speaking, reading, listening and writing. Also, it is possible that this model forms a greater focus and motivational aspect to study the subject in a foreign language at an even greater level, spending not $50 \%$ of the time, but all $100 \%$. Today, the CLIL methodology is very common in Western Europe. For example, according to this method, bilingual educational institutions in Bulgaria provide such subjects as History, Geography, Philosophy in English, German, French, Spanish and other languages ${ }^{143}$.

This model allows undergraduates to surround themselves with a constant language environment and when learning a subject to interact with academic staff and other undergraduates involuntarily communicating in a foreign language.

\section{Elements of Content and Language Integrated Learning}

In order to train future professionals using the technique of subjectlanguage integrated learning, use the following elements of CLIL, known as " $4 \mathrm{C}$ ":

- Content;

- Cognition;

- Communication;

- Culture.

The content means first of all understanding, development of knowledge, skills and abilities in a certain subject area. In the classroom it is necessary to stimulate the process of learning and develop skills within the subject being studied, to understand the essence and master new concepts and features of the subject, taking into account previous

\footnotetext{
${ }^{143}$ Педагогическое мастерство : материалы VIII Междунар. науч. конф. (2016). Москва. $16 \mathrm{c.}$
} 
experience. Within the framework of this methodological approach, the semantic component is system-forming ${ }^{144}$.

This element defines goals, objectives and topics in order to implement the right professional opinion and self-expression. Content is a kind of basis for studying the subject. Content is a set of elements and processes that make up a given object or phenomenon. To study the subject in a foreign language and understand the above component. For instance, the content, in the training of specialists perform exercises to understand the content. When teaching mathematics, undergraduates are given tasks to perform, and above all they must understand the content of the problem, the necessary condition for its solution.

Learners should not start solving it without understanding its conditions, for example, its content. Therefore, acquaintance with the task includes the actual mastery of its content and checking the awareness of undergraduates.

Cognition, perception, an important component that carries the development of mental abilities. CLIL stimulates cognitive and mental skills. Why is it necessary to develop thinking? - To better understand a foreign language and the subject studied, to create analysis and logical thinking, to build chains of relationship. After all, "good CLIL practice is due to cognitive activity" 145 . Cognition also presupposes the ability to use the acquired knowledge and skills in order to learn to express one's thoughts not only in the native language, but also in a foreign language. It should be noted that the cognitive concept can stimulate the development of cognitive abilities.

To achieve this goal, analytical and writing tasks will help, in which you need to find a logical answer to the question, find the main idea, by thinking, finding connections and comparing facts. In addition, cognitive activity can be successfully developed by performing listening exercises, i.e. listening to segments in a foreign language within a given topic and subject.

\footnotetext{
${ }^{144}$ Coyle D., Hood Ph., Marsh D. (2010). CLIL, Content and Language Integrated Learning. Cambridge. P. 4-12.

${ }^{145}$ Bentley K. (2010). The TKT Course CLIL Module. University of Cambridge. P. 6-7.
} 
Communication, or a language, which has a special status, because it is a means of learning the material, a kind of tool of cognition and a means of communication, whether monologue or dialogic communication. Moreover, language serves as a subject for study. Direct contact between communicators on a particular topic within the subject helps to reflect the form of thinking, using expressive means and speech directly in a foreign language. Through communication, you can implement such an important component as cognitive thinking, as well as express your thoughts on the content in a foreign language. Most importantly, undergraduates not only use a foreign language to study the chosen subject, but also the subject itself to practice communication and expression in a foreign language. It is also worth noting that during communication the lexical stock in a given topic increases, which is not an important component. If we talk about the tasks to be performed in order to develop communication techniques, it will help to discuss texts, articles, especially with the use of lexical series within a given topic, analysis of the main idea and topic. When discussing a topic in a foreign language, the teacher should minimize their speech and encourage undergraduates to increase feedback and discuss the topic, integrating language skills ${ }^{146}$. This principle is the main goal in the CLIL method when it comes to the communicative factor.

Moreover, listening tasks are well suited for the development of communication, because listening is a type of foreign language speech activity in the context of the peculiarities of the development of language mechanisms.

It should be emphasized that communication is very closely linked to culture. Culture is the core of the CLIL methodology. Culture presupposes culturological knowledge and a set of material and spiritual values, which include an understanding of cultural aspects, features and analysis of how similar and different individual cultures are.

Culture helps to understand yourself and others, to better understand the culture of your country and other countries. In addition, undergraduates who study, this component will encourage the

\footnotetext{
${ }^{146}$ Marsh D. (2002). CLIL. The European Dimension: Actions, Trends and Foresight Potential. Brussels. P. 4-16.
} 
preservation of cultural values and stimulate them to improve and develop culture in general, to identify for themselves the main vectors in the education and awareness of cultural significance. With the strengthening of the functional role of foreign languages and taking into account the requirements of modern society, there is a need to train professionals who will be able to effectively carry out the process of intercultural communication. This involves the formation of not only language but also cognitive awareness of the learning process. Since the CLIL method involves subject-language integration, it is important to understand that in the world cultural space a person must not only speak the language, but also interact with other cultures, in other words, integrate and immerse themselves in intercultural interactions. Therefore, when training international future professionals, it is necessary to take into account all the facets and concepts, trends and features of different cultures of the world. This will allow to form an appropriate level of cultural and communicative competence. It should be noted that all 4C components cannot exist separately from each other as separate independent elements. They are closely related to each other and special attention should be paid when teaching the subject of development of each of the elements.

\section{Applying CLIL at online classes}

Remote teaching with the application of CLIL methodology can seem for many undergraduates to be a difficult and not understandable issue but it is not. Online differs from live studying with the absence of live contact face-to-face, however, it cannot prevent you from effective studying of this or that discipline in another language as there is a set contact between an undergraduate and an aacademic staff member while distance classes through the screen of a laptop or a mobile phone. In fact, the gadget does not resist from full deepening into the subject via online technology.

CLIL classes can be varied depending on the learning content. However, there are several permanent stages that can help plan quality work:

1) selection of a topic of interest (for language specialties); topic according to the program (for non-language specialties); 
2) selection of vocabulary $-6-10$ terms at the initial stage, which can later be increased to 20 , depending on the level of preparation of students;

3) selection of grammatical structures;

4) use of text - at any CLIL lesson, reading and listening are of principal importance as basic perceptual skills when mastering new material. Reading and listening involves the use of ready-made texts on a specific topic with the provision of all necessary information. It can be scientific literature (theses, articles, monographs), educational and methodical literature (manuals, reference books, schemes), Internet resources. It is this material that substantiates the lexical and grammatical selection;

5) the formation of a graphic organizer. A graphic organizer is a tool for written communication that uses graphic notation to represent knowledge, concepts, ideas, and the relationships and relationships between them. As a didactic tool that performs illustrative, communicative and cognitive functions, graphic organizers are used not only as information carriers, but also as support for undergraduates' activities when planning educational projects in solving problems, decision-making, research. Graphic organizers differ in several ways:

- chain organizers - temporal chart, block diagrams;

- graphical comparisons;

- comparison - diagrams with logical relationships;

- hierarchical organizers - pyramid diagrams, tree diagrams, etc.;

- conceptual organizers - map concept.

Thus, the goal is to visualize the received information so that the undergraduate has the opportunity to analyze it, to rely on this visualization when repeating the material, preparing homework, independent and individual work;

6) the use of information in a creative way, which can be directly related to the types of independent and individual work, classroom work - depending on the time, which involves the implementation of arbitrary oral and written tasks (projects, cases, essays - everything that allows the undergraduate to personalize information that will naturally, from the point of view of psychology, improve the perception and assimilation of the material). 
Here there are some forms, techniques and methods presented according to the method of CLIL. The most productive are "5-minute interview activity", "ABC dictation", "Grab it!", "True / False dictation", "Balloon debate".

5-minute interview activity is a tool that allows you to organize activities that promote a good atmosphere, prepares students for further work. The essence of this technique is to write each student some interrogative sentences in English. Everyone in turn answers all the questions. Thus, it is possible to achieve "disclosure" of students, develop their listening and speaking skills, as well as develop attentiveness.

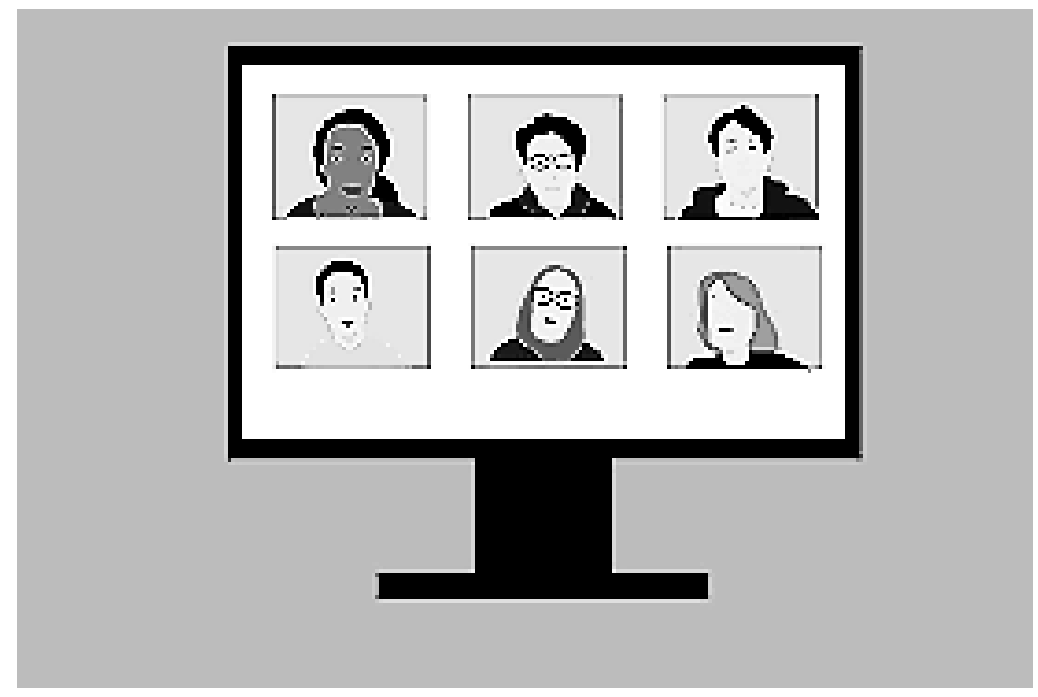

$A B C$ dictation is a non-traditional dictation, which involves showing a picture with further questions about the associative number of undergraduates. Then the academic staff member reads a couple of sentences from the text in accordance with the provided picture to each of the participants, after which the participants discuss the information obtained, perform tasks according to the acquired knowledge. This technique allows you to improve lexical and grammatical skills, introduces the culture of foreign speakers. 

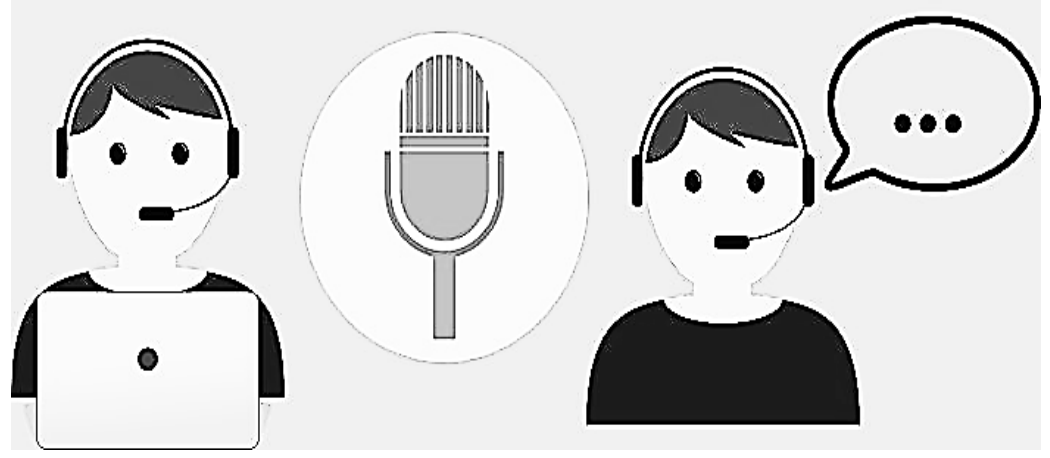

Grab it! - admission to work together: the academic staff member provides students with the writing of some terms in accordance with the topic of the lesson. One participant from each group is determined by the speaker, who is given definitions of these terms. The speaker announces the definition, and his group must choose the right term.

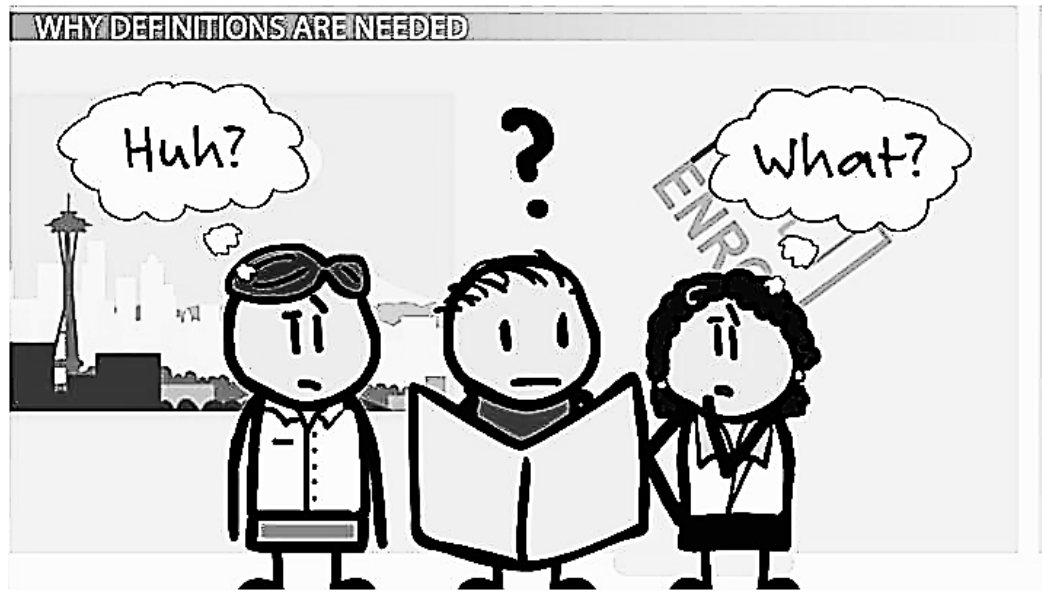

True / False dictation is a technique in which the academic staff member reads three theses on a topic, and students have to guess which one is incorrect. the correct theses are written in the abstract. 


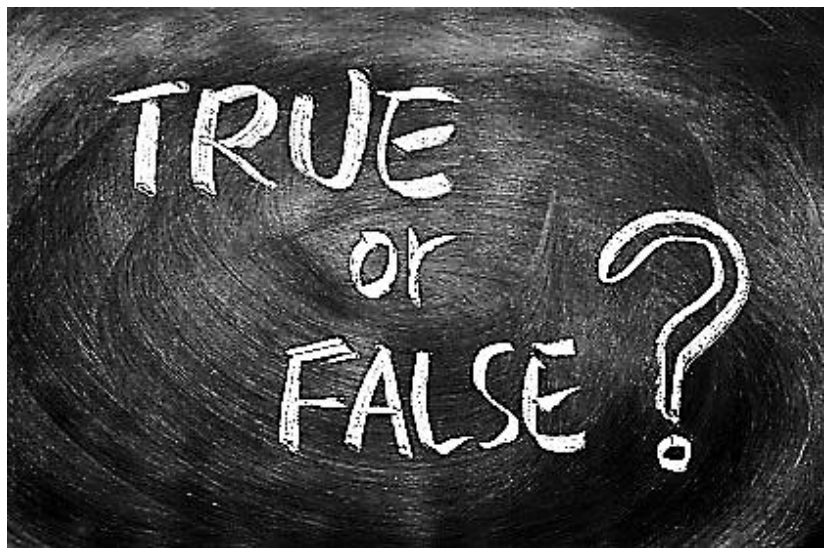

Balloon debate - a task during which undergraduates given with the names / photos of four scientists (according to the topic of the lesson). The students discuss the most important contributions of these scientists and identifies the most influential of them. The speakesr present the chosen scientist, giving arguments, facts and examples. In order to reduce the stress / fear of public speaking, the speaker is given a balloon as a means of distraction.

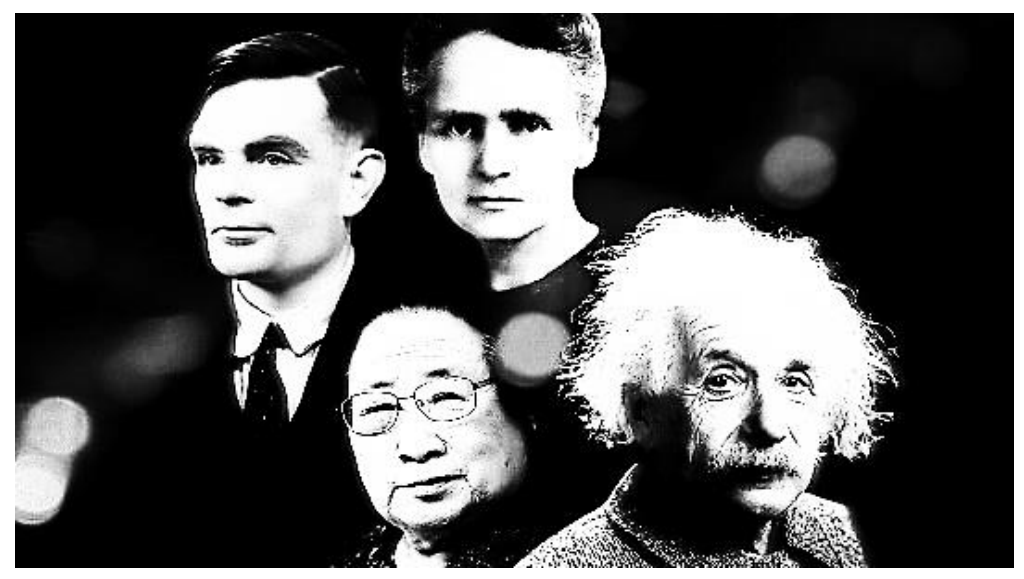

Lessonup - the teacher uses online quiz-tool of her or his choice, but I like Lessonup because of the different types of questions you can ask. It 
is an online plantform used for showing videos, images, questions and quizzes. It allows students to join your virtual classroom with their devices.

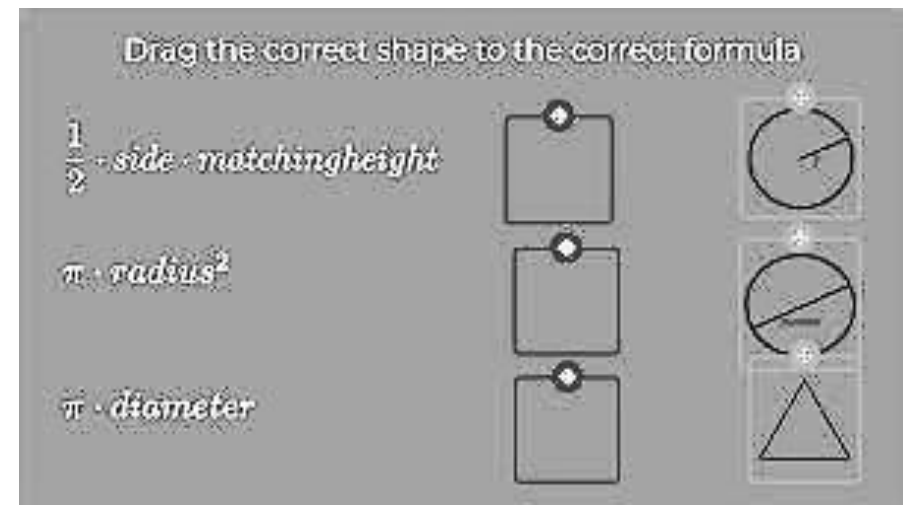

\section{CONCLUSIONS}

The main advantage of the CLIL method is the increase of motivation of undergraduates to study the subject, it becomes more interesting for them to master the subject by learning a foreign language. Language learning through the subject and subject learning through the language deal with the use of technology over the internet, which relates closely to the online language learning environment. Another advantage is that during classes using CLIL undergraduates can immerse themselves in the language environment and learn more about a foreign language and all its subtleties and facets. Students also develop cultural and communicative competence; they have the opportunity to better understand the culture of language. In addition, the CLIL technique helps them to expand their vocabulary in a particular subject, learn new language techniques, expand terminology in the field of a particular terminology, which will help future professionals in their future work as an international specialist. Thanks to the techniques offered by CLIL, undergraduates can also develop their creative and logical thinking, and above all their outlook. Moreover, the study of a foreign language in a professional subject context becomes a priority, because the future specialist is motivated by the goal of acquiring competence in 
a particular professional field at the international level. Online CLIL classes are varied according to the learning content. However, you can trace several permanent stages that will help plan quality work: the selection of topics of interest; vocabulary selection; selection of grammatical structures; use of text; formation of a graphic organizer; use of information in a creative way. The most productive techniques and ways of the CLIL method are "5-minute interview activity", "ABC dictation", "Grab it!", "True/False dictation", "Balloon debate", "Lessonup".

\section{SUMMARY}

The article is dedicated to CLIL methodology usage during training international specialists via remote teaching. The general peculiarities and principles of using CLIL methods, main advantageous aspects are discussed. CLIL is revealed as a successful and commonly distributed approach for integrating foreign language into study process of various curriculum disciplines. Content and Language Integrated Learning refers to teaching undergraduates different subjects through a foreign language. CLIL has several advantages that include: bilingual immerse, development of mental abilities, logic, creative and cognitive thinking, enhancement of communication skills, expansion of world outlook and increase cultural competence. Various techniques of studying disciplines in foreign language remote teaching are proposed.

\section{REFERENCES}

1. Брыксина И. Е. (2009). Концепция билингвального/ бикультурного языкового образования в высшей школе (неязыковые специальности). Тамбов. С. 14.

2. Дебич М. А. (2017). Інтернаціоналізація вищої освіти: світовий досвід : монографія. Суми. 291 с.

3. Лалетина Т. А. (2012). Интегрированный подход и использование предметно-языковой интеграции при обучении иностранному языку. Красноярск. С. 16.

4. Педагогическое мастерство : материалы VIII Междунар. науч. конф. (2016). Москва. С. 16. 
5. Филология и лингвистика в современном мире (2017). Международная научная конференция. Москва. 94 с.

6. Bentley K. (2010). The TKT Course CLIL Module, University of Cambridge. P. 6-7.

7. Brewster J. (2004). Content-based language teaching: a way to keep students motivated and challenged? Canterbury. P. 5.

8. Candelier, M., Oomen, I. (2002). Linguarum. The Gateway to Languages. The Introduction of language awareness into the curriculum: Awakening to language. Council of Europe Publishing. P. 18.

9. Coelen R. (2016). A Learner-Centred Internationalisation of Higher Education. In Global and Local Internationalization. Boston. P. 35-42.

10. Coyle D., Hood Ph., Marsh D. (2010). CLIL, Content and Language Integrated Learning. Cambridge. P. 4-12.

11. Marsh D. (2002). CLIL. The European Dimension: Actions, Trends and Foresight Potential. Brussels. P. 4-16.

12. Mehisto, P., Frigols, M.-J., \& Marsh, D. (2008). Uncovering CLIL. MacMillan. P. 240. 